\title{
Special Issue on Roads to Reference
}

This special issue of MANUSCRITO collects original articles by leading scholars from Latin America and Spain about topics discussed in Mário Gómez-Torrente's recent book Roads to Reference: An Essay on Reference Fixing in Natural Language (2019). Each article is followed by GómezTorrente's reply.

The idea of the issue grew out of a workshop on GómezTorrente's book organized in July $16^{\text {th }} 2020$ at the Instituto de Investigaciones Filosóficas (UNAM).

We hope the issue will increment the interest for this book in particular and bring a substantial contribution to the discussion of central topics in contemporary analytic philosophy.

MARCO RUFFINO

https:/ /orcid.org/0000-0001-5619-0016

(Editor in Chief of MANUSCRITO)

Department of Philosophy

University of Campinas

Campinas-S.P., Brazil

ruffinomarco@gmail.com

https://doi.org/10.1590/0100-6045.2020.V43N4.MR

\section{REFERENCES}

Gómez-Torrente, M. (2019). Roads to Reference: An Essay on Reference Fixing in Natural Language. Oxford University Press.

$((c))$ EY 